\title{
АНАЛИЗ ПРОЦЕССА ВЫВОДА СВЧ ЭНЕРГИИ ИЗ РЕЗОНАТОРА УПРАВЛЯЕМОЙ ТРАНСФОРМАЦИЕЙ ВИДА КОЛЕБАНИЙ*
}

\author{
АРТЕМЕНКО С. Н., ИГУМНОВ В. С. \\ Национальный исследовательский Томский политехнический университет, \\ Россия, Томск, 634050, пр-т Ленина, 30
}

\begin{abstract}
Аннотация. Рассмотрена работа резонансного СВЧ компрессора с выводом энергии управляемой трансформацией вида колебаний на окне связи резонатора с короткозамкнутым волноводным шлейфом. Методом матрицы рассеяния на модели устройства выполнен анализ процесса вывода при трансформации добротного вида в предельно низкодобротный вид. Получены выражения для описания переходных процессов при накоплении и выводе. Показано, что в исследуемом компрессоре возможно формирование СВЧ импульсов с регулируемой мощностью, длительностью и формой огибающей
\end{abstract}

Ключевые слова: СВЧ компрессор, волноводный Н-тройник, интерференционный переключатель, резонатор, коммутатор

\section{ВВЕДЕНИЕ}

В последние 10-20 лет вырос интерес к пассивному способу повышения мощности импульсного СВЧ излучения, основанному на накоплении энергии СВЧ импульса в резонаторе и быстром ее выводе в нагрузку [1]. Pеализующие способ резонансные СВЧ компрессоры отличаются простотой и невысокой стоимостью. В то же время, они значительно увеличивают импульсную мощность СВЧ излучения (до 20-23 дБ), имеют высокую мощность выходных импульсов $(0,001-1$ ГВТ) и способны работать с высокой частотой повторения (0,1-1 кГц и выше) [2-6]. Это обеспечивает возможность их эффективного использования в различных областях науки и техники. В частности, резонансные СВЧ компрессоры находят применение в ускорительной технике [4], исследованиях воздействия СВЧ импульсов на электронные приборы и их элементную базу [5], в радиолокации [6] и ряде других областей науки и техники.

В силу принципа работы, известные компрессоры формируют импульсы СВЧ с фиксированным усилением и неизменной длительностью и огибающей, что ограничивает их функциональные возможности.

В [7] экспериментально показана возможность формирования импульсов СВЧ с регулируемыми параметрами в компрессоре с выводом энергии трансформацией вида колебаний на окне связи резонатора с короткозамкнутым волноводным шлейфом. Схема резонансного СВЧ компрессора (рис. 1) содержит накопительный резонатор 1 , устройство ввода энер-

* Работа выполнена в рамках Государственного задания «Наука» Минобрнауки РФ № 0.1323.2014. 